\title{
Types of Intelligences as Predictors of Self-Efficacy: A Study on Iranian EFL Students
}

\section{Mojtaba Aghajani ${ }^{1 *}$}

* Correspondence:

Mojtaba_Aghajani45@yahoo.com

${ }^{1}$ Khatam ol Anbia University, Tehran, Iran

Received: 16 March 2018

Revision: 2 May, 2018

Accepted: 19 July 2018

Published online: 20 December 2018

\begin{abstract}
Through the implementation of the multiple intelligences, teachers and practitioners will see an increase in their students' performance and ability to learn languages. The application of multiple intelligences theory is suggested as a structured way to address and understand the holistic nature of learners' diversity. It is a favorable tool for teachers to increase the attractiveness of language learning tasks and, therefore, create motivational conditions. Intelligence is not just a single construct which traditionally was assumed to be constant throughout a person's life; individual's profiles of intelligence differ in terms of encouragement, training, and circumstances to enquire materials eliciting particular intelligences. The present study was an attempt to investigate types of intelligences (linguistic, logicalmathematical, visual, kinesthetic, musical, interpersonal, and intrapersonal) as predictors of self-efficacy (generalized self-efficacy, academic selfefficacy, and self-regulatory efficacy). The participants were 148 male and female Iranian B.A. students majoring in TEFL and Translation at the Islamic Azad University in Malayer. The instruments included a 100-item Michigan test, Gardner's MI questionnaire, a 12-item general self-efficacy scale, an 8-item academic self-efficacy, and an 11-item self-efficacy for selfregulated learning. Data were analyzed through multiple regression analyses. Results indicated that musical and linguistic intelligences were predictors of general self-efficacy and spatial /visual intelligence made a significant contribution to predicting self-efficacy for self-regulated learning while academic self- efficacy could not be predicted by any of the intelligence types.
\end{abstract}

Keywords: multiple intelligences, self-efficacy, academic self-efficacy, self-regulated learning 


\section{Introduction}

Gardner states that unlike traditional general intelligence that focuses on two linguistic and logical-mathematical intelligences, individuals possess other seven distinct intelligences considered within a cultural context: visual, kinesthetic, musical, interpersonal, intrapersonal, naturalist, and existential intelligences. All individuals apply them to solve problems, invent processes, and create things (Gardner, 1993; Gokhan \& Omer, 2010). According to Smith (2001), Gardner believes that intelligence is not just a single construct which traditionally was assumed to be constant throughout a person's life; individual's profiles of intelligence differ in terms of encouragement, training, and circumstances to enquire materials eliciting particular intelligences.

The application of multiple intelligences theory (MIT) is suggested as a structured way to address and understand the holistic nature of learners' diversity. It is a favorable tool for teachers to increase the attractiveness of language learning tasks and, therefore, create motivational conditions (Arnold \& Fonseka, 2004; Christison, 1996). Current research provides evidence that learners' multiple intelligences are more valuable for effective performance than a combination of knowledge, skills, and capabilities like overall intelligence (Jaeger, 2003).

Another issue of increasing importance is learner beliefs about their potentials. According to Cinkara and Tilfarlioğlu (2009), the advent of Bandura's theories was in the 1960s when he started to introduce his social-behavioral theory. Learner beliefs, known as self-efficacy (SE), is a term used to refer to a person's beliefs in his or her ability to organize and execute a required course of action to achieve a desired result, which play a key role in the learning process. Bandura posits four sources of self-efficacy including Mastery Experiences, Vicarious Experience or Modeling, Social Persuasion, and Physiological Factors (Bandura, 1977).

People with high self-efficacy are more likely to make efforts to complete a task, and to persist longer in those efforts than those with low self-efficacy. Efficacy beliefs help accomplishments motivationally through strategic thinking (Caprara et al., 2008; Schunk, 1990). Efficacy is individuals' future-oriented judgment about their competence rather than their actual level of competence. This is an important distinction since people usually overestimate or underestimate their actual abilities (Woolfolk Hoy \& Burke Spero, 2005). In the past two decades, researchers have found links between student achievement and three kinds of efficacy - the self-efficacy of students, the sense of efficacy of teachers, and the collective efficacy of schools (Goddard et al., 2000; Pajares, 1996). The self-efficacy of students is the focus of this investigation.

Through the implementation of the multiple intelligences, teachers will see an increase in their students' performance and ability to learn (Kolata, 2003). Thus, by integrating multiple intelligences, there will be possibilities of considering diverse learners and empowering their sense of responsibility and efficacy as learners.

The present study aims to answer the following research questions:

1. Which type of multiple intelligences is a better predictor of generalized self-efficacy?

2. Which type of multiple intelligences is a better predictor of academic self-efficacy?

3. Which type of multiple intelligences is a better predictor of self-regulatory efficacy?

\section{Review of the Literature}

Although many studies on MI have been conducted during the last two decades, few of them have explored the interrelationship between MI and self-efficacy, especially in foreign language learning situations. The present study seeks to investigate the role of multiple intelligences in predicting the learners' sense of self-efficacy. As far as exploring such a relationship in an Iranian context is concerned, to the researcher's best knowledge, no such research has been conducted. Thus, this study aims to discover which type of multiple intelligences is a better predictor of selfefficacy.

Many researchers have explored the relationship between emotional intelligence and self-efficacy of EFL teachers (Gürola et al., 2010; Nikoopour et al., 2012; Schutte et al., 1998) and learners (Hashemi \& Ghanizadeh, 2011). Besides, few studies like Chan (2003), have explored the relationship between teachers' multiple intelligences and their self efficacy. Although many studies have been conducted on these areas, rarely they have taken into consideration the different levels of intellectual abilities the leaner possesses, such as the types of intelligences. This justifies the need for studies relating MI theory aimed at fostering learners' intelligence profiles to learners' self-efficacy. Therefore, the purpose of the present study is two-fold. First, it examines the existence of relationships among learners' multiple 
intelligences and their self-efficacy. Second, it attempts to see to what extent or in what combination Gardner's intelligence types are predictors of self-efficacy.

Learners' efficacy for academic activities can be improved by the belief that they are capable to regulate their own learning procedure (Zimmerman \& Bandura, 1994). According to Zimmerman et al. (1992), self-efficacy for selfregulated learning affects academic achievement through its influence on academic self-efficacy. They note that training learners to set goals for themselves strengthens their self-efficacy and academic performance. Because selfregulatory efficacy and academic self-efficacy are two prominent aspects influencing the extent of learners' selfefficacy, this study aims to measure these two constructs besides participants' generalized self-efficacy with the purpose of investigating the relationship of the proposed three factors, generalized self-efficacy, academic selfefficacy, and self-regulatory efficacy, with the learners ' multiple intelligences.

Most previous studies in the field of second and foreign language learning have been conducted from the learners' perspective, and learners play a vital role in investigations. So, learner variables such as self-efficacy and multiple intelligences assume considerable importance. Since there are few studies done before in Iran investigating these two constructs, namely self-efficacy and multiple intelligences, the researcher believes that they need to be explored to see the role of MI in predicting the self-efficacy of Iranian learners. Given the paucity of research on multiple intelligences, which affect learners' self-efficacy, the results of the present study can be fruitful for Iranian teachers and learners. Furthermore, there is no study showing the existence of a relationship between self-efficacy and multiple intelligences in Iran; therefore, the findings can assist teachers in using the new information in their teaching.

\section{Methodology}

\subsection{Design of the Study}

This study utilized a descriptive, ex-post facto research design to address the research questions of the present study.

\subsection{Participants}

The initial number of participants in the present study was 180 male and female Iranian B.A. students majoring in TEFL and Translation at the Islamic Azad University of Malayer, Hamedan, Iran. 10 of the students did not answer the Michigan test, leaving a total number of 170 participants. 18 other participants were excluded from the study because of extremely high or low levels of proficiency measured through by the Michigan Test of English Language Proficiency. Therefore, the final number of participants included 148 students.

\subsection{Instruments}

In this research, 5 instruments were utilized:

\section{A Michigan Test (MTELP)}

The MTELP in the present study included a 100-item multiple choice test consisting of three subparts, vocabulary, grammar, and reading comprehension (GVR).

\section{A MI Questionnaire:}

A Multiple Intelligences test based on Howard Gardner's MI Model was administered to the participants to specify their intelligence profile. It measured seven dimensions of Gardner's MI theory: linguistic, logical/mathematical, musical, spatial, bodily/kinesthetic, interpersonal, and intrapersonal intelligences. It comprised a set of 35 statements with 5 statements specified for assessing each of the intelligences.

\section{General Self-efficacy Scale:}

This scale, which is the modified version of Sherer's General Self efficacy (SGSES), consisted of 12 items (Bosscher \& Smit, 1998).

\section{Academic Self-efficacy:}

The academic self-efficacy (ASE) is the individual perceptions about the effectiveness with which one can perform academic tasks or achieve academically (Chemers, Hu, \& Garcia, 2001). 


\section{Self-efficacy for self-regulated learning:}

This study used Bandura's (1977) self-efficacy for self-regulated learning scale composed 11 items that measure participants' perceived capabilities to use a variety of self-regulated learning strategies.

\subsection{Procedure}

Initially, the participants were explained about the study procedures, and they were asked to complete the study materials and then to return the completed pack to the researcher directly or via the mail system. The number of packs distributed was 180, and out of those, 170 were returned. Then, a pre-test, which was a multiple choice test of MTELP, was administered to make sure that there was no significant difference among learners in terms of their proficiency level. In order to select a homogeneous group of participants, their scores on the general proficiency test were summarized, and the mean and standard deviation were computed; those students whose scores were less than one standard deviation away from (above or below) the mean were selected as the sample of the present study, and those with extremely high or low levels of proficiency were excluded from all subsequent analyses.

In another session, Gardner's MI questionnaire and three other questionnaires including general self-efficacy scale, academic self-efficacy, and self-efficacy for self-regulated learning were administered. The MI questionnaire was used to measure the participants' MI profiles. They were required to place a tick mark for statements with which they agreed and a dash for those they disagreed. In the following session, the self-efficacy scales consisting of 3 types of self-efficacies - general self-efficacy, academic self-efficacy, and self-efficacy for self-regulated learning - were used to measure the learners' efficacy. Students rated their general self-efficacy according to a five-point Likert scale. The descriptions were 1, disagree strongly; 2, disagree moderately; 3 , neither agree nor disagree for 3, 4, agree moderately; and 5, agree strongly. The approximate time for the completion of the MI questionnaire and the self-efficacy scales was between 15 to 20 minutes.

\section{Findings and Data Analysis}

The first question attempted to see which types of MIs are predictors of general self-efficacy scale. To this end, a multiple regression analysis was used. The results of the descriptive statistics for the general self-efficacy scale and the types of intelligences of the learners are presented in Table 1.

Table 1. Descriptive statistics for general self-efficacy and multiple intelligences

\begin{tabular}{llll}
\hline & Mean & Std. Deviation & $\mathrm{N}$ \\
\hline GSE & 38.2905 & 7.53699 & 148 \\
Linguistic & 2.8176 & 1.31985 & 148 \\
Logical/math & 2.8514 & 1.03256 & 148 \\
Musical & 2.9797 & 1.17496 & 148 \\
Bodily/kinesth & 3.5068 & 1.22611 & 148 \\
Spatial / visual & 3.0608 & 1.10796 & 148 \\
Interpersonal & 3.6622 & 1.09764 & 148 \\
Intrapersonal & 3.3378 & 1.23748 & 148 \\
\hline
\end{tabular}

Table 1 shows that interpersonal intelligence group's mean score is the highest (=3.66) and linguistic and logical/mathematical intelligences groups mean scores are the lowest $(=2.8)$. A correlation coefficient was run between general self-efficacy of the students and their types of MI to see the degree of the relationship between them. The results are shown in Table 2. 
As it is shown in Table 2, of all the seven predictors, only linguistic and musical intelligences account for a statistically significant correlation with general self-efficacy $(\mathrm{p}<.05)$.

Table 2. Correlations among general self-efficacy and multiple intelligences

\begin{tabular}{|c|c|c|c|c|c|c|c|c|c|}
\hline & & $\begin{array}{l}\text { Q } \\
\text { 足 }\end{array}$ & 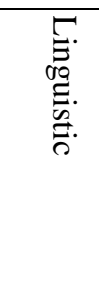 & 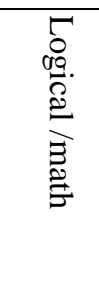 & 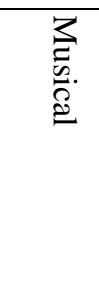 & 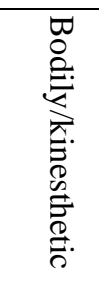 & 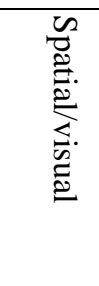 & 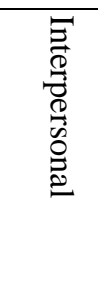 & 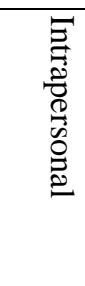 \\
\hline \multirow{8}{*}{ Pearson Correlation } & GSE & 1.000 & .249 & -.025 & .287 & .106 & .023 & -.016 & .046 \\
\hline & Linguistic & & 1.000 & .100 & -.011 & .049 & .170 & .056 & -.133 \\
\hline & Logical/math & & & 1.000 & -.120 & .098 & -.040 & 207 & .141 \\
\hline & Musical & & & & 1.000 & .234 & -.276 & .163 & -.089 \\
\hline & Bodily/kinesth & & & & & 1.000 & -.158 & .143 & -.082 \\
\hline & Spatial/ visual & & & & & & 1.000 & .073 & .079 \\
\hline & Interpersonal & & & & & & & 1.000 & .065 \\
\hline & Intrapersonal & & & & & & & & 1.000 \\
\hline \multirow{8}{*}{$\begin{array}{l}\text { Sig. } \\
\text { (1-tailed) }\end{array}$} & GSE & & .001 & .381 & .000 & .100 & .390 & .423 & .288 \\
\hline & Linguistic & & . & .114 & .446 & 277 & .019 & .250 & .054 \\
\hline & Logical/math & & & . & .073 & 119 & .316 & .006 & .044 \\
\hline & Musical & & & & . & .002 & .000 & .024 & 141 \\
\hline & Bodily/kinesth & & & & & . & .028 & .041 & .160 \\
\hline & Spatial/ visual & & & & & & . & 189 & .169 \\
\hline & Interpersonal & & & & & & & & 218 \\
\hline & Intrapersonal & & & & & & & & . \\
\hline $\mathrm{N}$ & GSE & 148 & 148 & 148 & 148 & 148 & 148 & 148 & 148 \\
\hline
\end{tabular}

To further analyze the data, a stepwise multiple regression was used and the result is presented in Table 3 . It indicates that among the seven components of the MI profile, only two of them, i. e. musical and linguistic intelligences predict general self-efficacy. The other types of intelligences did not contribute to the regression model (Stepwise criteria: probability of $\mathrm{F}<=.05)$. 
Table 3. Variables Entered/ Removed ${ }^{\mathrm{a}}$

\begin{tabular}{|c|c|c|c|}
\hline Model & $\begin{array}{l}\text { Variables } \\
\text { Entered }\end{array}$ & $\begin{array}{l}\text { Variables } \\
\text { Removed }\end{array}$ & Method \\
\hline 1 & musical & . & $\begin{array}{l}\text { Stepwise (Criteria: Probability-of-F-to-enter <= } \\
.050 \text {, Probability-of-F-to-remove }>=.100 \text { ). }\end{array}$ \\
\hline 2 & linguistic & . & $\begin{array}{l}\text { Stepwise (Criteria: Probability-of-F-to-enter <= } \\
.050 \text {, Probability-of-F-to-remove }>=.100 \text { ). }\end{array}$ \\
\hline
\end{tabular}

a. Dependent variable: GSE

The result of the model summary (Table 4 ) shows that musical intelligence shared $0.08 \%$ of variance with general self-efficacy while, together, the linguistic and musical intelligences account for around $0.14 \%$ of the total variance with general self-efficacy.

Table 4. Model Summary

\begin{tabular}{lcccc}
\hline Model & $\mathrm{R}$ & $\mathrm{R}$ Square & $\begin{array}{l}\text { Adjusted } \\
\text { Square }\end{array}$ & $\begin{array}{c}\text { R Std. Error of the } \\
\text { Estimate }\end{array}$ \\
\hline 1 & $.287^{\mathrm{a}}$ & .082 & .076 & 7.24414 \\
2 & $.382^{\mathrm{b}}$ & .146 & .134 & 7.01293 \\
\hline
\end{tabular}

a. Predictors: (Constant), musical

b. Predictors: (Constant), musical, linguistic

c. Dependent variable: GSE

The results of the ANOVA (Table 5) indicate that both $\mathrm{F}$-values are statistically significant $\left(\mathrm{F}_{(1,146)}=13.12, \mathrm{p}<.05\right.$; $\left.\mathrm{F}_{(2,145)}=12.39, \mathrm{p}<.05\right)$. The results show that the predictive power of the model is significant. 
Table 5. ANOVAc on general self-efficacy

\begin{tabular}{lllllll}
\hline Model & & Sum of Squares & df & Mean Square & F & Sig. \\
\hline 1 & Regression & 688.778 & 1 & 688.778 & 13.125 & $.000^{\mathrm{a}}$ \\
& Residual & 7661.729 & 146 & 52.478 & & \\
& Total & 8350.507 & 147 & & & \\
\hline 2 & Regression & 1219.236 & 2 & 609.618 & 12.395 & $.000^{\mathrm{b}}$ \\
& Residual & 7131.271 & 145 & 49.181 & & \\
& Total & 8350.507 & 147 & & & \\
& & & & & \\
& &
\end{tabular}

a. Predictors: (Constant), musical

b. Predictors: (Constant), musical, linguistic

c. Dependent Variable: GSE

Table 6 contains the unstandardized as well as standardized coefficients of the two models, along with the observed $\mathrm{t}$-values and significance levels. The first model shows that for every one standard deviation of change in one's musical intelligence, there will be about 28 of a standard deviation change in one's general self-efficacy. The second model shows that when musical and linguistic intelligences are taken together, for every one standard deviation change in one's musical and linguistic intelligences, there will be .29 and .25 of a standard deviation change in one's general self-efficacy, respectively. Meanwhile, all the standardized coefficients are statistically significant.

Table 6. Coefficients ${ }^{\mathrm{a}}$ of Multiple Intelligences

\begin{tabular}{lllllll}
\hline \multirow{2}{*}{ Model } & \multicolumn{3}{l}{$\begin{array}{l}\text { Unstandardized } \\
\text { Coefficients }\end{array}$} & $\begin{array}{l}\text { Standardized } \\
\text { Coefficients }\end{array}$ & $\mathrm{t}$ & Sig. \\
\hline \multirow{2}{*}{1} & $\mathrm{~B}$ & Std. Error & Beta & \\
\cline { 3 - 7 } & (Constant) & 32.801 & 1.628 & & 20.148 & .000 \\
& musical & 1.842 & .509 & .287 & 3.623 & .000 \\
\hline 2 & (Constant) & 28.692 & 2.012 & & 14.258 & .000 \\
& musical & 1.860 & .492 & .290 & 3.779 & .000 \\
& linguistic & 1.439 & .438 & .252 & 3.284 & .001 \\
\hline
\end{tabular}

a. Dependent variable: GSE

These results indicate that two types of intelligences including musical and linguistic intelligences are predictors of general self-efficacy. Therefore, the first null hypothesis is rejected. The second research question of the present study aimed to find out which intelligence types were the best predictors of academic self-efficacy. To this end, a standard multiple regression and a stepwise regression analysis were run on the data with academic self-efficacy as a criterion variable and the seven types of MI as predictor variables. A correlation was run to see the degree of the relationship among academic self-efficacy and types of MI (Table 7). The results indicated that none of the intelligence types had 
any significant correlation with academic self-efficacy. In addition, none of the 7 intelligences entered into the regression model. Therefore, the second null hypothesis was supported.

Table 7. Correlations among academic self-efficacy and multiple intelligences

\begin{tabular}{|c|c|c|c|c|c|c|c|c|c|}
\hline & & $\begin{array}{l}\text { 品 } \\
\text { T1 }\end{array}$ & 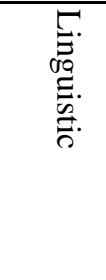 & 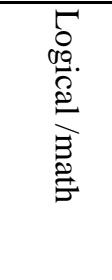 & 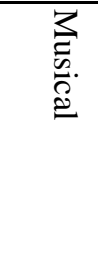 & 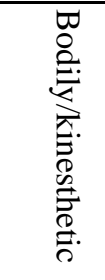 & 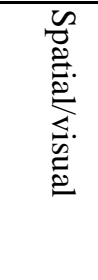 & 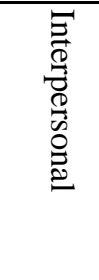 & 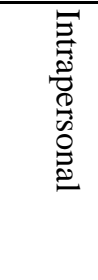 \\
\hline \multirow{8}{*}{ Pearson Correlation } & ASE & 1.000 & .043 & -.030 & -.132 & -.032 & .101 & -.076 & .125 \\
\hline & Linguistic & & 1.000 & .100 & -.011 & .049 & .170 & .056 & -.133 \\
\hline & Logical/math & & & 1.000 & -.120 & .098 & -.040 & .207 & .141 \\
\hline & Musical & & & & 1.000 & .234 & -.276 & .163 & -.089 \\
\hline & Bodily/kinesthetic & & & & & 1.000 & -.158 & .143 & -.082 \\
\hline & Spatial/ visual & & & & & & 1.000 & .073 & .079 \\
\hline & Interpersonal & & & & & & & 1.000 & .065 \\
\hline & Intrapersonal & & & & & & & & 1.000 \\
\hline \multirow{8}{*}{$\begin{array}{l}\text { Sig. } \\
\text { (1-tailed) }\end{array}$} & ASE & & .302 & .359 & .055 & .351 & .110 & .180 & .064 \\
\hline & Linguistic & & & .114 & .446 & .277 & .019 & .250 & .054 \\
\hline & Logical/math & & & & .073 & .119 & .316 & .006 & .044 \\
\hline & Musical & & & & & .002 & .000 & .024 & .141 \\
\hline & Bodily/kinesthetic & & & & & & .028 & .041 & .160 \\
\hline & Spatial/ visual & & & & & & & .189 & .169 \\
\hline & Interpersonal & & & & & & & & .218 \\
\hline & Intrapersonal & & & & & & & & \\
\hline $\mathrm{N}$ & ASE & 148 & 148 & 148 & 148 & 148 & 148 & 148 & 148 \\
\hline
\end{tabular}

The third research question attempts to see which types of MIs are the best predictors of self-efficacy for self-regulated learning. 
Table 8. Descriptive statistics for self-regulatory efficacy and multiple intelligences

\begin{tabular}{llll}
\hline & Mean & Std. Deviation N \\
\hline SRE & & & \\
Linguistic & 36.7297 & 8.17961 & 148 \\
Logical/math & 2.8176 & 1.31985 & 148 \\
Musical & 2.8514 & 1.03256 & 148 \\
Bodily/kinesthetic & 2.9797 & 1.17496 & 148 \\
Spatial / visual & 3.5068 & 1.22611 & 148 \\
Interpersonal & 3.0608 & 1.10796 & 148 \\
Intrapersonal & 3.6622 & 1.09764 & 148 \\
\hline
\end{tabular}

Table 8 shows the results of descriptive statistics for the self-regulatory efficacy and the types of intelligences of the learners. Table 8 shows that the intrapersonal intelligence group's mean score is the highest mean $(=3.66)$ and the linguistic and logical/ mathematic intelligences have the lowest mean $(=2.8)$. To see the degree of the relationship between self-efficacy for self-regulated learning and the seven types of intelligences, a correlation coefficient was run. The results are shown in Table 9 As it is shown in Table 9, only spatial/visual intelligence accounts for a statistically significant correlation with self-regulatory efficacy $(\mathrm{p}<.05)$. 
Table 9. Correlations among self-regulatory efficacy and multiple intelligences

\begin{tabular}{|c|c|c|c|c|c|c|c|c|c|}
\hline & & $\begin{array}{l}\tilde{\pi} \\
\tilde{\pi}\end{array}$ & 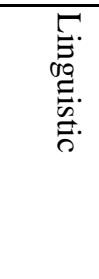 & 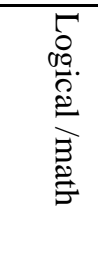 & 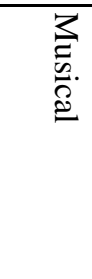 & 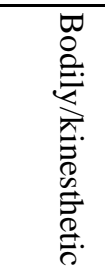 & 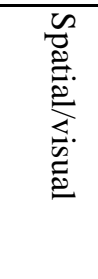 & 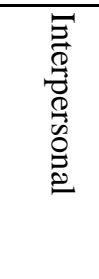 & 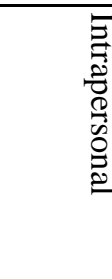 \\
\hline \multirow{8}{*}{ Pearson Correlation } & SRE & 1.000 & -.002 & -.049 & -.146 & .013 & .217 & .036 & -.016 \\
\hline & Linguistic & & 1.000 & .100 & -.011 & .049 & .170 & .056 & -.133 \\
\hline & Logical/math & & & 1.000 & -.120 & .098 & -.040 & 207 & 141 \\
\hline & Musical & & & & 1.000 & .234 & -.276 & .163 & -.089 \\
\hline & Bodily/kinesthetic & & & & & 1.000 & -.158 & 143 & -.082 \\
\hline & Spatial/ visual & & & & & & 1.000 & .073 & .079 \\
\hline & Interpersonal & & & & & & & 1.000 & .065 \\
\hline & Intrapersonal & & & & & & & & 1.000 \\
\hline \multirow{8}{*}{$\begin{array}{l}\text { Sig. } \\
\text { (1-tailed) }\end{array}$} & SRE & & .490 & 277 & .038 & 437 & .004 & .332 & .421 \\
\hline & Linguistic & & & .114 & .446 & .277 & .019 & .250 & .054 \\
\hline & Logical/math & & & & .073 & .119 & .316 & .006 & .044 \\
\hline & Musical & & & & & .002 & .000 & .024 & .141 \\
\hline & Bodily/kinesthetic & & & & & & .028 & .041 & .160 \\
\hline & Spatial/ visual & & & & & & & .189 & .169 \\
\hline & Interpersonal & & & & & & & & .218 \\
\hline & Intrapersonal & & & & & & & & \\
\hline $\mathrm{N}$ & SRE & 148 & 148 & 148 & 148 & 148 & 148 & 148 & 148 \\
\hline
\end{tabular}

The result of a stepwise multiple regression is presented in Table 10. It shows that among the seven intelligences, spatial/visual intelligence is the only predictor entered into the regression equation. The other components of MI profile did not contribute to the regression model (Stepwise criteria: probability of $\mathrm{F}<=.05$ ). 
Table 10. Variables entered/ removed

\begin{tabular}{lll}
\hline $\begin{array}{l}\text { Model } \\
\text { entered }\end{array}$ & $\begin{array}{l}\text { Variables } \\
\text { removed }\end{array}$ & Method \\
\hline 1 & Spatial/visual. & $\begin{array}{l}\text { Stepwise }(\text { Criteria: Probability-of-F-to-enter }<=.050, \text { Probability-of-F-to- } \\
\text { remove }>=.100) .\end{array}$
\end{tabular}

a. Dependent variable: GSE

The result of the model summary presented in Table 11 shows that spatial/visual intelligence shared 0.047 of the variance with self-regulatory efficacy.

Table 11. Model Summary ${ }^{\mathrm{b}}$

\begin{tabular}{|c|c|c|c|c|}
\hline Model & $\mathrm{R}$ & R Square & $\begin{array}{l}\text { Adjusted R } \\
\text { Square }\end{array}$ & Std. Error of the Estimate \\
\hline 1 & $.217^{\mathrm{a}}$ & .047 & .041 & 8.01153 \\
\hline
\end{tabular}

a. Predictors: (Constant), Spatial/visual

b. Dependent variable: SRE

The result of ANOVA test presented in Table 12 shows that $\mathrm{F}$-value is statically significant $\left(\mathrm{F}_{(1,146}=7.23, \mathrm{p}<.05\right)$. The results show that the predictive power of the model is significant.

Table 12. ANOVA ${ }^{\mathrm{b}}$ on self-regulatory efficacy

\begin{tabular}{lllllll}
\hline Model & & Sum of Squares & df & Mean Square & F & Sig. \\
\hline 1 & Regression & 464.228 & 1 & 464.228 & 7.233 & $.008^{\mathrm{a}}$ \\
& Residual & 9370.962 & 146 & 64.185 & & \\
& Total & 9835.189 & 147 & & & \\
\hline
\end{tabular}

a. Predictors: (Constant), Spatial/ visual

b. Dependent variable: SRE

Table 13 contains the unstandardized as well as standardized coefficients of the two models, along with the observed t-values and significance levels. The model shows that for every one standard deviation of change in one's spatial/visual intelligence, there will be about .21 of a standard deviation change in one's self-regulatory efficacy. The standardized coefficient is statistically significant. 
Table 13. Coefficients of multiple intelligences

\begin{tabular}{|c|c|c|c|c|c|c|}
\hline \multicolumn{2}{|l|}{ Model } & \multicolumn{2}{|c|}{$\begin{array}{l}\text { Unstandardized } \\
\text { Coefficients }\end{array}$} & $\begin{array}{l}\text { Standardized } \\
\text { Coefficients }\end{array}$ & \multirow[t]{2}{*}{$\mathrm{t}$} & \multirow[t]{2}{*}{ Sig. } \\
\hline & & B & Std. Error & Beta & & \\
\hline \multirow[t]{2}{*}{1} & (Constant) & 31.820 & 1.941 & & 16.397 & .000 \\
\hline & $\begin{array}{l}\text { Spatial/ } \\
\text { visual }\end{array}$ & 1.604 & .596 & .217 & 2.689 & .008 \\
\hline
\end{tabular}

a. Dependent variable: SRE

These results indicate that spatial/visual intelligence is a predictor of self-efficacy for self-regulated learning. Therefore, the third null hypothesis is also rejected.

\section{Discussion}

The purpose of this study was to determine the types of MIs as predictors of self-efficacy. The findings of some previous studies (Beichner, 2011; Shore, 2001; Yazdanimoghaddam \& Khoshroodi, 2010) are partially similar to the results of the present study, which emphasize MI as predictors of self-efficacy. Yazdanimoghaddam and Khoshroodi (2010) concluded that linguistic and musical intelligences are the two main predictors of teachers' teaching efficacy. This is in partial accordance with the findings of the present study since the same two types of intelligences turned out to be predictors of general self-efficacy.

Furthermore, the findings of the present study partially approve those of Shore (2001), and Beichner (2011). Shore (2001) investigated the relationship between MI and student self-efficacy. It was concluded that MI-based classrooms would have a positive effect on self-efficacy in ESL courses. Although a relationship was found between MIs and self-efficacy, the present study does not lend full support to that finding. Shore's study showed relationship between writing self-efficacy and interpersonal, intrapersonal, bodily-kinesthetic, and linguistic intelligences.

Beichner (2011) showed a relationship between multiple intelligences and students' academic self-efficacy. He reported higher self-efficacy for students in classrooms where teachers used two of their three dominant MI than the other two groups, classrooms where the teacher used one of their three dominant MI and the other group in which none of students' dominant MI were emphasized. His study is compatible with the aim of the present study to find the existence of relationship between multiple intelligences and academic self-efficacy but without taking into account the types of MIs. However, the finding of the present study shows that learners' types of intelligence have no role in predicting their academic self-efficacy.

The findings of the present study are different from a number of previous studies presented in the review section. According to the present study, there is a positive correlation between self-regulatory efficacy and only the visual intelligence, but Mahasneh (2013) concluded that there is a significant positive correlation between students' selfregulatory efficacy and all kinds of intelligence.

A number of factors might have contributed to the results obtained in this study. This study was conducted with a small sample size of participants (180) while in studies like Mahasneh (2013), the number of participants was 576, and in Carroll et al. (2009), the participants included 935 learners. According to Caban (2004), the more significant change in self-efficacy is evident with a larger sample of participants.

The other possible factor resulting in different findings may be gender differences. In the present study, gender was not considered as a variable, but the previous studies on multiple intelligences like Nikoopour et al. (2012), Saricaoglu and Arikan (2009), Razmjoo (2008), Hanafye (2013), and Neto et al. (2008) have emphasized gender differences among the participants in MI-based instruction. The other significant factor seems to be learners' level of proficiency. The present study only focused on B.A. students majoring in Translation and TEFL. Most of the previous studies were conducted with advanced and upper-intermediate level participants. 


\section{Conclusion}

The present study attempted to investigate types of multiple intelligences as predictors of self-efficacy. The first question investigated the type of intelligence as the predictor of general self-efficacy. Findings showed that musical and linguistic intelligences are predictors of general self-efficacy. The second research question examined the intelligence types which predicted academic self-efficacy. The results indicated that none of the intelligence types contributed to predicting academic self-efficacy. The third question was concerned with the relationship between selfregulatory efficacy and multiple intelligences. Based on the obtained findings, spatial/visual intelligence is the only significant predictor of self-efficacy among the other types of intelligence. Based on the results of this research, it is concluded that learners' multiple intelligences made a contribution to predicting self-efficacy and some of the intelligence types are a better predictor of self-efficacy. This means that the enhancement of learners' MI will increase their level of self- efficacy and attention to learners MI profiles will raise learners' beliefs about their ability.

\section{References}

Arnold, J., \& Fonseca Mora, M. C. (2004). Multiple intelligence theory and foreign language learning: A brain-based perspective. IJES, 4(1), 119-136. https://revistas.um.es/ijes/article/view/48141

Bandura, A. (1977). Self-efficacy: Toward a unifying theory of behavioral change. Psychological Review, 84(2), 191215. http://dx.doi.org/10.1037/0033-295X.84.2.191

BAŞ, G., \& Beyhan, O. (2010). Effects of Multiple Intelligences supported project based learning on students' achievement level and attitude towards English lesson. International Electronic Journal of Elementary Education, 2(3), 365-386. https://files.eric.ed.gov/fulltext/EJ1052017.pdf

Beichner, R. A. (2011). The Relationship between students' academic self-efficacy and teachers' multiple intelligences instructional practices (Doctoral dissertation). Available from ProQuest Dissertations and Theses database.

Bosscher, R. J., \& Smit, J. H. (1998). Confirmatory factor analysis of the general self-efficacy scale. Behavior Research \& Therapy, 36(3), 339-343. https://doi.org/10.1016/S0005-7967(98)00025-4

Caban, A. R. (2004). Effects of hypnosis on the academic self-efficacy of first generation college student. Unpublished master's thesis, Department of Educational Leadership \& Counseling Psychology, Washington State University. https://research. $\quad$ wsulibs.wsu.edu/xmlui/bitstream/handle/2376/234/a_caban 072304. pdf?sequence $=1$

Caprara, G. V., Fida, R., Vecchione, M., Del Bove, G., Vecchio, G. M., Barbaranelli, C., \& Bandura, A. (2008). Longitudinal analysis of the role of perceived self-efficacy for Self-regulated learning in academic continuance and achievement. Personal determinants of academic achievement. Journal of Educational Psychology, 100(3), 525-534. doi: 10.1037/0022-0663.100.3.525

Chan, D. W. (2003). Multiple intelligences and perceived self-efficacy among Chinese secondary school teachers in Hong Kong. Educational Psychology, 23(5), 521-533. https://doi.org/10.1080/0144341032000123778

Chemers, M. M., Hu, L., \& Garcia, B. F. (2001). Academic self-efficacy and first year college student performance and adjustment. Journal of Educational Psychology, 93(1), 55-64. http://dx.doi.org/10.1037/00220663.93.1.55

Christison, M. A. (1996). Teaching and learning languages through multiple intelligences. TESOL Journal, 6(1), 1014.

Tilfarlioğlu, F. T., \& Cinkara, E. (2009). Self-efficacy in EFL: Differences among proficiency groups and relationship with success. Novitas- ROYAL, 3(2), 129-142. www.novitasroyal.org/Vol_3_2/tilfarlioglu.pdf

Gardner, H. (1993). Multiple intelligences: The theory in practice. New York: Basic books.

Goddard, R. D., Hoy, W. K., \& Woolfolk Hoy, A. (2000). Collective teacher efficacy: its meaning, measure, and effect bon student achievement. American Education Research Journal, 37(2), 479-507. doi: 10.2307/1163531 https://www.jstor.org/stable/1163531 
Gürola, A., Özercana,M, G., \& Yalçin, H. (2010). A comparative analysis of pre-service teachers' perceptions of selfefficacy and emotional intelligence. Procedia Social and Behavioral Sciences, 2(2), 3246-3251. https://doi.org/10.1016/j.sbspro.2010.03.496

Hanafiyeh, M. (2013). The relationship between Iranian EFL learners' MI and success in foreign language learning. Asian Journal of Management Sciences \& Education, 2(1), 97-105. www.ajmse.leenaluna.co.jp/AJMSEPDFs/Vol.2(1)/AJMSE2013(2.1-09).pdf

Hashemi, M. R., \& Ghanizadeh, A. (2011). Emotional intelligence and self-efficacy: A case of Iranian EFL university students. International Journal of Linguistics, 3(1), 1-16. doi: 10.5296/ijl.v3i1.877

Jaeger, A. J. (2003). Job competencies and the curriculum: an inquiry into emotional intelligence in graduate professional education. Research in Higher Education, 44(6), 615-639. doi: 10.1023/A:1026119724265

Kolata, K. (2003). Increasing students' efficacy through the multiple intelligences: Promoting diversity in the classroom. IUSB Undergraduate Research Journal. http://www.iusb.edu/ journal/2001/kolata.html

Mahasneh, A. M. (2013). The relationship between multiple intelligence and self-efficacy among sample of Hashemite university students. International Journal of Education and Research, 1(5), 1-12. www.ijern.com/images/May-2013/33.pdf

Neto, F., Ruiz, F., \& Furham, A. (2008). Sex differences in self-estimation of multiple intelligences among Portuguese adolescents. High Ability Studies, 19(2), 189-204. https://doi.org/10.1080/13598130802504387

Nikoopour, J., Farsani, M, A., Tajbakhsh, M., \& Sadat Kiyaie, S. H. (2012). The relationship between trait emotional intelligence and self-efficacy among Iranian EFL teachers. Journal of Language Teaching and Research, 3(6), 1165-1174. doi: $10.4304 / j$ ltr.3.6.1165-1174

Pajares, F. (1996). Self-efficacy beliefs in academic settings. Review of Educational Research, 66(4), 543-578. doi: $\underline{10.2307 / 1170653}$

Razmjoo, S. A. (2008). On the relationship between multiple intelligences and language success. The Reading Matrix, $8(2), 155-174$. www.readingmatrix.com/articles/razmjoo/article.pdf

Saricaoglu, A., \& Arikan, A. (2009). A study of multiple intelligences, foreign language success and some selected variables. Journal of Theory and Practice in Education, 5(2), 110-122.

https://files.eric.ed.gov/fulltext/ED506218.pdf

Schunk, D. H. (1990). Goal setting and self-efficacy during self-regulated learning. Educational Psychologist, 25(1), 71-86. https://doi.org/10.1207/s15326985ep2501_6

Schutte, N. S., Malouff, J. M., Hall, L. E., Haggerty, D. J., Cooper, J. T., Golden, C. J., \& Dornheim, L. (1998). Development and validation of a measure of emotional intelligence. Personality and Individual Differences, 25(2), 167-177. https://nsuworks.nova.edu/cps_facarticles/506

Shore, J. R. (2001). An investigation of multiple intelligences and self-efficacy in the university English as a second language classroom. Doctoral dissertation, George Washington University. Retrieved July 19, 2008, from ProQuest Dissertations and Theses database (UMI No. 3029591).

Smith, E. (2001). Implication of multiple intelligences theory for second language learning. Post-Script, 2(1), 32-52.

Woolfolk Hoy, A. W., \& Burke Spero, R. (2005). Changes in teacher efficacy during the early years of teaching: A comparison of four measures. Teaching and Teacher Education, 21(4), 343-356. https://doi.org/10.1016/j.tate.2005.01.007

Yazdanimoghaddam, M., \& Khoshroodi, S. B. (2010). The relationship between teachers' teaching efficacy and their multiple intelligences. Journal of Language and Translation, 1(2), 33-39.

Zimmerman, B. J., \& Bandura, A. (1994). Impact of self-regulatory influences on writing course attainment. American Educational Research Journal, 31(4), 845-862. doi: 10.2307/1163397 https://www.jstor.org/stable/1163397 
Zimmerman, B. J., Bandura, A., \& Martinez-Pons, M. (1992). Self-motivation for academic attainment: The role of self-efficacy beliefs and personal goal setting. American Educational Research Journal, 29(3), 663-676. doi: $10.3102 / 00028312029003663\}$ 